\title{
Vegetable Rennet Tablets for Fresh Cheese Making
}

\author{
R. F. Sitepu ${ }^{1}$, N. Ginting ${ }^{1 *}$, G. W. Siregar ${ }^{1}$, and M. A. Purba ${ }^{2}$ \\ ${ }^{I}$ Animal Production Program Study, Faculty of Agriculture, Universitas Sumatera Utara, Padang \\ Bulan, Medan 20155, Indonesia \\ ${ }^{2}$ Feed Research Institute Graduate, School of Chinese Academy of AgricultureSciences, Beijing, \\ China \\ *Correspondent author: nurzainahginting@ gmail.com
}

\begin{abstract}
Indonesia has a Muslim population around 200 million and many make religious trips to Arabia and taste fresh cheese. Therefore, in Indonesia there is a demand for fresh cheese. In this regard, there is also a need to use a halal cheese starter. The purpose of this research is to prove that the use of plant-based rennet is able to produce fresh cheese which is also a halal rennet because it comes from plants. The study design is a completely randomized design (CRD) where factor $\mathrm{A}$ was the vegetable rennet dose $(\mathrm{g})$ ie $\mathrm{A} 0=$ without tablets, $\mathrm{A} 1=0.1 \mathrm{~A} 2=0.2 \mathrm{~A} 3=$

0.3 and factor $\mathrm{B}$ duration of storage (days) i.e., $\mathrm{B} 0=0$ days, $\mathrm{B} 1=5 \mathrm{~B} 2=10$ and $\mathrm{B} 3=15$. Variables measured include water content, dry matter, protein, fat from fresh cheese and analysis of the costof making fresh cheese with a commercial rennet starter compared to vegetable rennet. The results showed that the dosage of using vegetable rennet papain enzyme was $0.2 \mathrm{~g}$ and optimum storage time for 10 days in increasing protein content and dry matter content and being able to reduce fat and water content in fresh cheese from Murrah buffalo milk.
\end{abstract}

Keywords: Vegetable rennet, halal, fresh cheese, Murrah buffalo's milk

Received [5 July 2020] | Revised [25 July 2020] |Accepted [31 July 2020]

\section{Introduction}

At present there are around 207 million Muslim communities in Indonesia or around 87.2\% [1]. More than 1.4 million Indonesian Muslims carry out Umrah worship to Saudi Arabia every year [2].

One of the food products consumed by Indonesian Muslims in Saudi Arabia is fresh cheese. This is caused by the provided free food for all worshipers, among others in the form of bread with fresh Arabic cheese such as Nabulsi cheese at the mosque [3]. The delicious taste of Arabic cheese makes Indonesian Muslims want to taste it back in their country. Fresh cheese is the simplest cheese in terms of its manufacturing process because there is no ripening or maturating process. This type of cheese is the earliest product in making cheese in general. Fresh cheese is made from the coagulation of milk protein using acid or rennet, then pressed to separate the liquid portion (whey) from the curd formed [4]. 
The problem with making fresh cheese is with rennet. Rennet is not produced in Indonesia. Rennet is an enzyme that helps the process of milk protein clumping in making cheese. Generally, rennet is produced from the stomach of mammals such as cattle, goats, camels, or pigs [5]. Rennet in Indonesia is the result of imports from various countries, such as Australia. The lack of rennet in Indonesia makes this imported rennet expensive and rare.

Rennet produced from non-Muslim countries raises the question of whether the rennet is processed from animals that are slaughtered following Islamic law. Therefore, we need another ingredient to replace rennet to be used in making cheese, among others by looking for other ingredients that contain protease enzymes. One source of the protease enzyme can be obtained from papaya sap [5]. The use of rennet substitutes from plants is also a solution to the reduction of slaughter of young ruminants that are still breastfeeding to obtain theenzyme protease from the stomach of the livestock.

In Arab countries, fresh cheese is made using goat's milk. This is due to the fact that the majority of livestock raised are goats, so that goat milk is abundant, and the prices are cheap. Unlike in Indonesia, not many dairy goats are found. Therefore, in this study Murrah buffalo milk is used because the price of milk is much cheaper than goat milk. According to [6] buffalo milk contains more fat and protein than goat's milk. The taste of buffalo milk is more concentrated because it contains more than $16 \%$ dry matter (total solid). Fatty levels of buffalo milk are around 6-8\%. Buffalo milk protein contains more casein, a little more albumin, and globulin.

[7] states that buffalo milk fat is easier to digest and contains complete minerals besides the curd protein is softer making it possible to make cheese.

The purpose of this study is to find alternatives to commercial rennet that are in accordance with Islamic law by utilizing the enzyme papain in making fresh cheese. In this study, the enzyme papain was made in tablet form such as commercial rennet. In an effort to achieve these objectives, we conducted research on physical characteristics (curd weight and curd yield), chemical composition (water content, dry matter content, fat content and protein content). In addition, the calculation of the cost of making fresh cheese using vegetable rennet compared to commercial rennet to determine the feasibility of using plant rennet.

\section{Materials and Method}

The research design used was a completely randomized design (CRD) factorial pattern with two factors, which were tested with the following treatment:

Factor A (papain enzyme level)

$\mathrm{A} 0=0.2 \mathrm{~g}$ (using commercial rennet) 
$\mathrm{A} 1=0.1 \mathrm{~g}$ of the papain enzyme

$\mathrm{A} 2=0.2 \mathrm{~g}$ of the papain enzyme

$\mathrm{A} 3=0.3 \mathrm{~g}$ of the papain enzyme

Factor B (storage time)

$\mathrm{B} 0=0$-day storage

$\mathrm{B} 1=5$ days storage

$\mathrm{B} 2=10$ days storage

$\mathrm{B} 3=15$ days storage

Number of tests: 2

The study began with the manufacture of vegetable rennet tablets.

The making of rennet tablets consists of several stages namely rennet extraction, drying and tableting. The scheme for making rennet tablets is as follows:

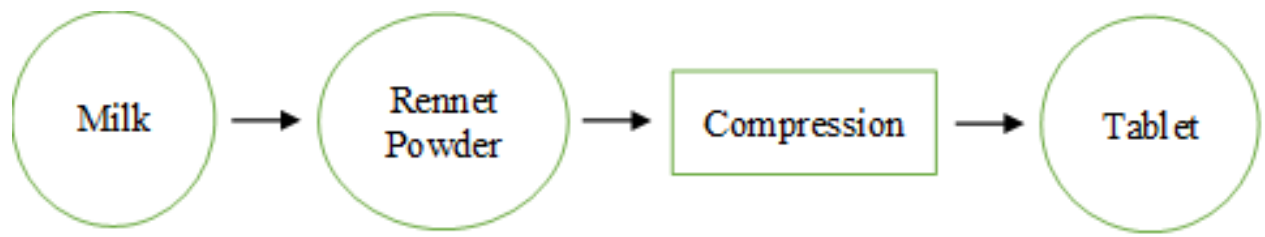

Figure 1. The scheme for making rennet tablets

The ingredients formula for making tablets consist of the enzyme's papain, primogel, lactose, talc, magnesium starch, starch malihot and distilled water. 


\subsection{Research Scheme}

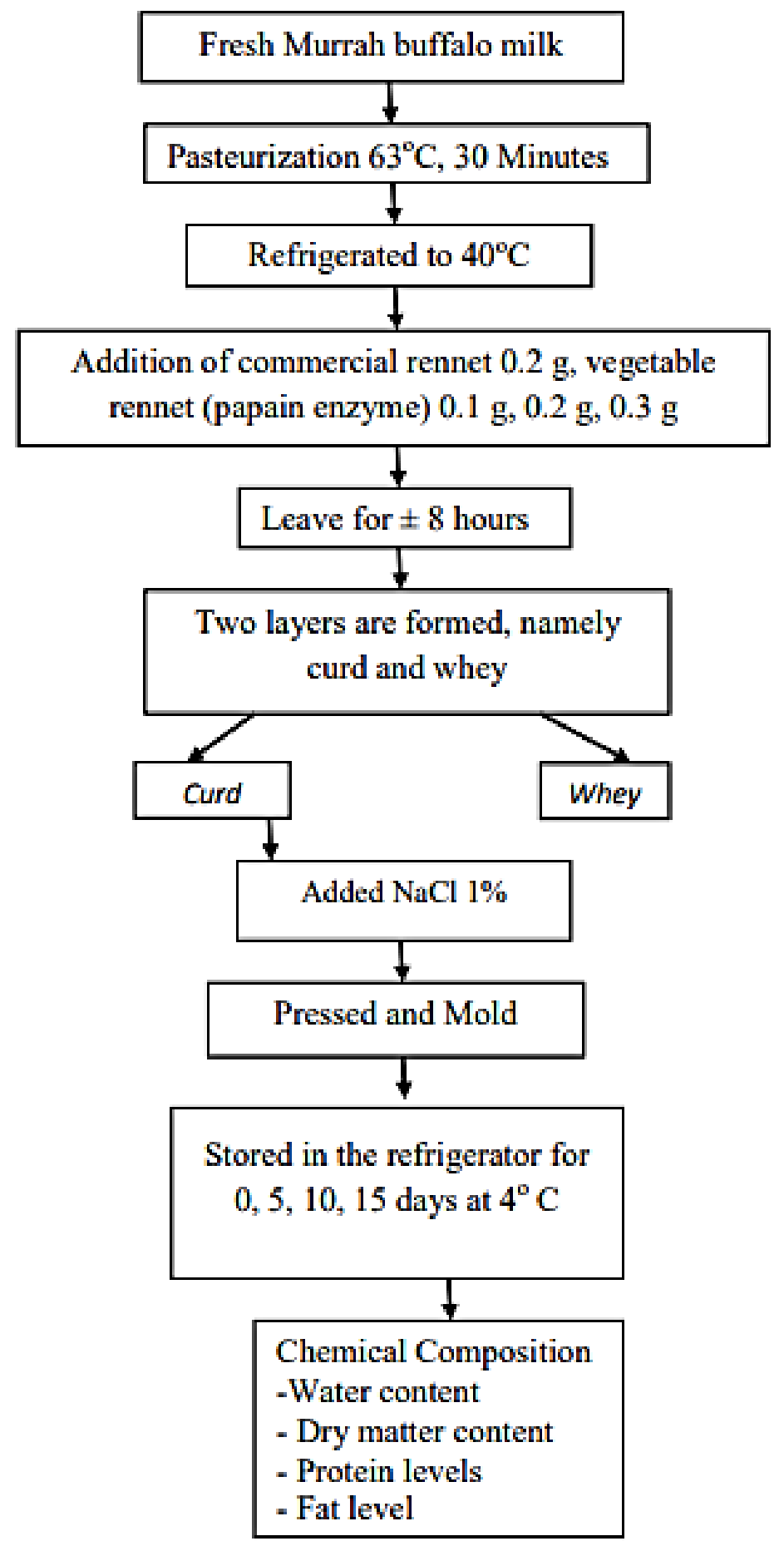

Figure 2. Research Scheme

\subsection{Research Parameter}

Chemical Composition Test

- Water content

Water content is carried out by means of drying. The water content of the sampleis calculated by the formula: 


$$
\mathrm{M}=\frac{\mathrm{A}-\mathrm{B}}{\mathrm{A}} \times 100 \%
$$

Note:

M: Water content of sample

A: Weight of fresh samples

B: Weight of sample after drying

- Dry Matter Content

The level of dry matter can be calculated by the formula:

\section{Dry matter $=$ Weight of cheese - Water content}

Taken by counting the weight of the cheese reduced by water content.

- Protein levels

Water content using the Kjedhal method. This method uses the Gerhardtkejeldaterm destruction unit. The percentage is calculated using the formula:

$$
\begin{aligned}
& \% \mathrm{~N}=\frac{(\mathrm{ml} \mathrm{NaOH} \text { blanko }-\mathrm{ml} \mathrm{NaOH} \text { sampel }) \times 14,008 \times \mathrm{N} \mathrm{NaOH}}{\text { Sample weight }} \times 100 \% \\
& \mathrm{KP}=\% \mathrm{~N} \times 6,38
\end{aligned}
$$

Note:

$\% \mathrm{~N} \quad$ : Nitrogen percentage

KP : Protein Level

14,008 : Nitrogen molecular weight

$\mathrm{N} \mathrm{NaOH}$ : Normality of $\mathrm{NaOH}$

6,38: Cheese conversion factor

- Fat Level

Fat content is applied by extraction according to Soxhlet. The sample was weighed as much as 5 grams of the sample and dried in an oven of $100^{\circ} \mathrm{C}$ to a constant weight, then put into a sling from filter paper and put into a soxhlet device containing a petroleum ether solvent. The material is then extracted for 3 hours then the sleeve with the material is dried in the oven for 45 minutes and 
putin a desiccator for 15 minutes, weighed until the weight is balanced. The difference in weight before and after extraction per sample weight is thepercentage of fat extracted.

$$
\mathrm{KL}=\frac{\mathrm{a}-\mathrm{b}}{\mathrm{a}} \times 100 \%
$$

Note:

KL : Fat level

A : Dry weight before extraction (gr)

B : Dry weight after extraction (gr)

\section{Results and Discussion}

\subsection{Water Content}

The results of the analysis of water content by giving commercial rennet 0.2 gand giving vegetable rennet papain enzyme $0.1 \mathrm{~g}, 0.2 \mathrm{~g}, 0.3 \mathrm{~g}$ and storage time 0 days, 5 days, 10 days, 15 days are presented in Table 1 following.

Table 1. Water content in Cheese

\begin{tabular}{crrrrr}
\hline \multirow{2}{*}{ Papain Enzyme } & \multicolumn{4}{c}{ Storage Time (B) } & \multirow{2}{*}{ Average } \\
\cline { 2 - 5 } Level (A) & \multirow{2}{*}{ B0 (0 day) } & B1 (5 days) & B2 (10 days) & \multirow{2}{*}{ B3 (15 days) } & \\
\cline { 1 - 5 } A0 & 49,87 & 50,87 & 51,69 & 48,67 & $50,27^{\mathrm{B}}$ \\
A1 & 60,83 & 59,51 & 56,24 & 56,95 & $58,38^{\mathrm{A}}$ \\
A2 & 59,80 & 61,21 & 57,48 & 58,31 & $59,45^{\mathrm{A}}$ \\
A3 & 62,42 & 61,25 & 57,96 & 59,10 & $60,17^{\mathrm{A}}$ \\
\hline Average & $58,22^{\text {th }}$ & $58,20^{\text {th }}$ & $55,84^{\text {th }}$ & $56,01^{\text {tn }}$ & \\
\hline
\end{tabular}

Note: Different superscripts in the same row and column show very significantdifferences $(\mathrm{P}$ $<0.01)$.

From the above table, the water content in cheese with animal rennet clumping ranges from $48.67 \%$ - 51.69\% while the water content in cheese with vegetable rennet clumping papain enzyme ranges from $56.24 \%-62.42 \%$. The same thing also happened in the study [8] the water content in all fresh cheese treatments produced had a water content in the range of $55.40 \%$ to $58.81 \%$. Fromthe results of this study note that the curd formed from fresh cheese water content with various doses treatment A1, A2, A3 obtained an average that is equal to $58.38 \%-60.17 \%$ while the animal rennet treatment (A0) obtained an average an average of 50.27\%. Fresh cheese water content in treatments A1, A2, A3 with an average storage time was 55.84\% - 58.20\% while in animal rennet (A0) an average of $58.22 \%$ was obtained.

The dosage administration of papain enzyme has a very significant effect $(\mathrm{P}<0.01)$ on the water content of cheese. The water content in cheese using animal rennet is lower than the water content 
in cheese with papain rennetclumping. The highest water content was found in treatment A3, with an average of 60.17. This is in accordance with statement [8] setting the water content in nonfat Gouda cheese minimum of $57 \%$. Therefore, all Gouda semi-hard cheeses did not meet the specified water content quality standards. The low water contentin the non-fat ingredients of Gouda cheese is thought to occur because the cheeseproduction process is still incomplete, for example at the stage of whey removal or pressing too long can cause a lot of water that comes out with the liquid whey.

The results of analysis of variance in fresh cheese on the storage durationdid not significantly influence $(\mathrm{P}>0.05)$ on the water content in cheese. The interaction between the dose of the enzyme papain and the duration of storagehad no significant effect $(\mathrm{P}>0.05)$ (in appendix 1) on the water content of the cheese. This is because the difference in the water content of cheese is thought to be caused by the presence of water in the cheese, which is in three levels, namely 1) bound in the structure of the curd component, 2) held against curd particlesthat are hygroscopic and 3) as free water. This is also suspected by [9] The presence of free water in cheese is influenced by the degree of emphasis at the time of whey release.

\subsection{Dry Matter}

The results of the analysis of dry matter content by giving commercial rennet $0.2 \mathrm{~g}$ and giving vegetable rennet papain enzyme $0.1 \mathrm{~g}, 0.2 \mathrm{~g}, 0.3 \mathrm{~g}$ and storage time 0 days, 5 days, 10 days, 15 days are presented in Table 2 .

Table 2. Dry Matter content in cheese

\begin{tabular}{crrrrr}
\hline \multirow{2}{*}{ Papain Enzyme } & \multicolumn{4}{c}{ Storage Time (B) } & \multirow{2}{*}{ Average } \\
\cline { 2 - 5 } Level (A) & \multirow{2}{*}{ B0 (0 day) } & B1 (5 days) & B2 (10 days) & B3 (15 days) & \\
\cline { 1 - 5 } A0 & 50,13 & 49,14 & 48,31 & 51,34 & $49,72^{\mathrm{A}}$ \\
A1 & 39,17 & 40,49 & 43,80 & 43,06 & $41,62^{\mathrm{B}}$ \\
A2 & 40,20 & 38,79 & 45,15 & 40,67 & $40,54^{\mathrm{B}}$ \\
A3 & 37,59 & 38,75 & 42,04 & 40,91 & $39,82^{\mathrm{B}}$ \\
\hline Average & $41,77^{\text {th }}$ & $41,79^{\text {th }}$ & $44,16^{\text {tn }}$ & $43,99^{\text {tn }}$ & \\
\hline
\end{tabular}

Note: Different superscripts in the same row and column show very significantdifferences $(\mathrm{P}$ $<0.01)$.

From the above table, the content of dry matter in cheese with commercial rennet clumpers is around $48.31 \%-51.34 \%$, while the content of drymatter in cheeses with vegetable rennet clumping is about $37.59 \%-45.15 \%$. The same thing also happened in the study [10] the content of dried cheese produced in the study ranged from $48,056 \%-57.54 \%$, the less water content contained in an ingredient or food product the more resistant and durable the product. Fromthe results of this study note that the curd formed from the levels of dry ingredients of fresh cheese with various doses with treatments A1, A2, A3 obtained an average of $39.82-41.62 \%$ while in the plant rennet treatment (A0) obtained an average an average of $49.72 \%$. The content of dry 
matter of fresh cheese in the treatment of A1, A2, A3 with the average storage time was $41.79 \%$ $-44.16 \%$. whereas in vegetable rennet (A0) an average of $41.77 \%$ was obtained.

The dosage administration of papain enzyme has a very significant effect $(\mathrm{P}<0.01)$ on the level of dry matter in cheese. The content of dry matter in cheese using animal rennet is higher than the levels of dry matter in cheese with rennet papain clumping. The highest level of dry matter was found in treatment A0, with an average of $40.72 \%$. According to [11] this is because animal rennet contains $80 \%$ chymosin enzyme and $20 \%$ pepsin.

The results of analysis of variance in fresh cheese on storage duration did not significantly influence $(\mathrm{P}>0.05)$ on dry matter content in cheese. The interaction between papain enzyme dosage and storage time did not significantly influence $(\mathrm{P}>0.05)$ on dry matter content in cheese. This was also suspected by [10]. The presence of free water in cheese is influenced by the degree of emphasis at the time of whey release.

\subsection{Protein Level}

The results of protein analysis with the administration of $0.2 \mathrm{~g}$ of commercial rennet and the administration of vegetable rennet papain enzyme $0.1 \mathrm{~g}, 0.2 \mathrm{~g}, 0.3 \mathrm{~g}$ and storage time of 0 days, 5 days, 10 days, 15 days are presented in Table 3.

Table 3. Protein level in cheese

\begin{tabular}{crrrrr}
\hline \multirow{2}{*}{ Papain Enzyme } & \multicolumn{4}{c}{ Storage Time (B) } & \multirow{2}{*}{ Average } \\
\cline { 2 - 5 } Level (A) & \multirow{2}{*}{ B0 (0 day) } & B1 (5 days) & B2 (10 days) & B3 (15 days) & \\
\cline { 1 - 5 } A0 & $12,52^{\mathrm{Bb}}$ & $11,68^{\mathrm{Bc}}$ & $11,65^{\mathrm{Bb}}$ & $12,56^{\mathrm{Ba}}$ & $49,72^{\mathrm{A}}$ \\
$\mathrm{A} 1$ & $12,47^{\mathrm{Ab}}$ & $11,95^{\mathrm{Ac}}$ & $12,91^{\mathrm{Ab}}$ & $16,72^{\mathrm{Aa}}$ & $41,62^{\mathrm{B}}$ \\
$\mathrm{A} 2$ & $12,21^{\mathrm{Ab}}$ & $12,34^{\mathrm{Ac}}$ & $13,57^{\mathrm{Ab}}$ & $17,60^{\mathrm{Aa}}$ & $40,54^{\mathrm{B}}$ \\
A3 & $13,53^{\mathrm{Ab}}$ & $13,09^{\mathrm{Ac}}$ & $15,10^{\mathrm{Ab}}$ & $11,99^{\mathrm{Aa}}$ & $39,82^{\mathrm{B}}$ \\
\hline Average & 12,68 & 12,26 & 13,30 & 14,71 & \\
\hline
\end{tabular}

Note: Different superscripts in the same row and column show very significantdifferences $(\mathrm{P}$ $<0.01)$.

From the table above, the protein level in cheese with animal rennetclumping is around $11.65 \%-12.56 \%$ while the protein level in cheese with vegetable rennet clumping is from the papain enzyme around $11.95 \%-17.60 \%$. The same thing happened in the study [12] known that an increase in protein level in cheese that utilizes the enzyme papain as a clot in making cheese. An increase in protein ranged from $14.86 \%-19.39 \%$. From the results of this study, it was found that curd formed from fresh cheese protein with various doses of vegetable rennet papain enzymes with A1, A2, A3 treatment obtained an average of $13.42 \%-13.92 \%$. while in the treatment of animal rennet (A0) an average of $12.10 \%$ was obtained. In the fresh cheese protein in the treatment of A1, A2, A3 with an average storage duration of $12.26 \%-14.71 \%$, while in animal rennet (A0) obtained an average of $12.68 \%$. 
The dosage administration of papain enzyme has a very significant effect $(\mathrm{P}<0.01)$ on the protein level in cheese. The protein in cheese that uses animal rennet is lower than the protein in cheese with rennet clumping papain enzyme. The highest protein level was in A2 treatment, with an average of $13.92 \%$. Thisis due to the high concentration of the papain enzyme and the increased dose of vegetable rennet papain enzyme given. This is in accordance with the literature when the concentration increases, the speed of the enzymatic reaction will rise to a certain point and finally constant [12]. From research [12] with the enzyme concentration variable it can be concluded that the optimal enzyme concentration in the manufacturing process is $0.4 \%$.

The results of analysis of variance in fresh cheese on the storage durationhad a very significant effect $(\mathrm{P}<0.01)$ on the protein level in cheese. The interaction between the dose of the enzyme papain and the shelf life has a very significant effect $(\mathrm{P}<0.01)$ on the protein level. This is because the microbial activity is still working during storage which will eventually change the composition of the cheese. [13] explained, during storage, there was a biochemical change in cheese. Supported by [14] which states that during storage, microbes change the composition of cheese.

\subsection{Fat Level}

The results of fat level analysis with the administration of $0.2 \mathrm{~g}$ commercial rennet and the administration of vegetable rennet papain enzyme $0.1 \mathrm{~g}, 0.2 \mathrm{~g}, 0.3 \mathrm{~g}$ and storage time 0 days, 5 days, 10 days, 15 days are presented in Table 4.

Table 4. Fat level on cheese

\begin{tabular}{|c|c|c|c|c|c|}
\hline \multirow{2}{*}{$\begin{array}{c}\text { Papain Enzyme } \\
\text { Level (A) }\end{array}$} & \multicolumn{4}{|c|}{ Storage Time (B) } & \multirow{2}{*}{ Average } \\
\hline & B0 (0 day) & B1 (5 days) & B2 (10 days) & B3 (15 days) & \\
\hline $\mathrm{A} 0$ & 61,19 & 61,05 & 57,17 & 58,36 & $59,44^{\mathrm{A}}$ \\
\hline A1 & 41,90 & 42,10 & 36,50 & 36,71 & $39,31^{\mathrm{B}}$ \\
\hline A2 & 50,35 & 40,99 & 39,51 & 47,93 & $44,69^{\mathrm{B}}$ \\
\hline $\mathrm{A} 3$ & 44,58 & 45,31 & 44,47 & 34,87 & $42,30^{\mathrm{B}}$ \\
\hline Average & $49,50^{\mathrm{tn}}$ & $47,37^{\mathrm{tn}}$ & $44,41^{\text {tn }}$ & $44,46^{\mathrm{tn}}$ & \\
\hline
\end{tabular}

Note: Different superscripts in the same row and column show very significantdifferences (P $<0.01)$.

From the table above, the fat level in cheese with animal rennet clumpingranges from $57.17 \%$ $61.19 \%$, while the fat level in cheese with vegetable rennetclumping papain enzyme ranges from $34.87 \%-50.35 \%$. The same thing happened to [14] dangke which is a processed food from nutritious buffalo milk with a fat level of $33.89 \%$. From the results of this study note that the curdformed from fat level of fresh cheese with various doses of vegetable rennet papain enzymes with treatment A1, A2, A3 obtained an average of $39.31 \%-44.69 \%$. while in the treatment of animal rennet (A0) obtained an average of 59.44\%. Fat level of fresh cheese in the treatment of A1, A2, A3 with the averagestorage time was $44.41 \%-47.37 \%$, whereas for animal rennet (A0) an average of $49.50 \%$ was obtained. 
The dosage of papain enzyme has a very significant effect $(\mathrm{P}<0.01)$ on fat level in cheese. The fat level of commercial cheese is higher than that of cheese with a lumpy dose of the enzyme papain. The highest fat is found in treatment $\mathrm{A}^{0}$.

In the control treatment using animal rennet found fat level with an average of 59.44\% while the lowest was found in the treatment dose of the addition of papain enzyme as much as $0.1 \mathrm{~g}$, with an average of $39.31 \%$. In the control treatment it was found that the fat level in the cheese continued todecrease, in the $\mathrm{B}^{0}$ treatment fat level in the cheese was $61.19 \%$ and in the $\mathrm{B} 3$ treatment the fat level in the cheese dropped to $58.36 \%$. Whereas in the treatmentwith other dosages of the enzyme papain also occurs a decrease in fat in the cheese at the storage time.

The shelf life of cheese has no significant effect $(\mathrm{P}>0.05)$ on fat level in cheese and the interaction between the dosage of papain enzyme administration and storage time has no significant effect $(\mathrm{P}>0.05)$ on fat level in cheese. [14] and [15] explains that the fat contained in cheese, during ripening, has been broken down into fatty acids (such as acetate, butyrate, caproic, stearic, oleic and others). These fatty acids will turn into various esters which will cause taste and aroma. Fat degradation as a result of the lipase enzyme derived from the activity of starter bacteria (Streptococcus lactis and Lactobacillus cremoris). Flying fatty acids formed are the result of lipolysis of cheese fat, an important component thatforms the taste, aroma, cohesiveness (body) and texture, both in soft cheese andin hard cheese.

\section{Conclusion}

Based on the results of the study note that the dosage of the use of vegetable rennet papain enzyme by $0.1 \mathrm{~g}$ and storage time for 10 days increases the protein content and levels of dry matter and reduces fat and water content in fresh cheeseMurrah buffalo milk.

\section{REFERENCES}

[1] Indonesia Statistic 2019.

[2] Akhmad Anwar Dani. Problematika Pengelolaan Penyelenggaraan Umrah di Kota Surakarta. Ilmu Dakwah: Academic Journal for Homiletic Studies Volume 12 Nomor 1 (2018) 23-45. 2018.

[3] Zebib, H. Nabulsi Knafeh/Kunafa/Knafeh Nabulsieh. Middle Eastern Recipes from Around the World. 2017.

[4] Johnson, M.E. 100-Year Review: Cheese Production and Quality. Journalof Dairy Science (Volume 100 Issue 12). 2017.

[5] Hutagalung, T.M., A. Yelnetty*, M. Tamasoleng, J. H. W. Ponto. Penggunaan enzim rennet dan bakteri lactobacillus plantarum yn 1.3 terhadap sifat sensoris keju. Jurnal Zootek (“Zootek” Journal) Vol. 37 No. 2: 286 - 293. 2017. 
[6] Mustakim, R. F. Muarifah, K.U. Al Awwaly. Pembuatan keju dengan menggunakan enzim renin Mucor pusillus amobi. Jurnal Ilmu-ilmu Peternakan 19 (2): 137 - 149. 2015.

[7] Sudono, A. Ilmu Produksi ternak Perah. Jurusan Ilmu Produksi ternak.Fakultas Peternakan.Institut Pertanian Bogor.

[8] Mudgal, V. D.1999. Milking buffalo. In: Sc. Falvey, and C. Chantalak hana (Eds), Smallholder dairying in the tropis. ILRI, Nairobi, Kenya. Pp. 101-116. 1999.

[9] Mudgal, V. D. Milking buffalo. In: Sc. Falvey, and C. Chantalak hana (Eds),

[10] Smallholder dairying in the tropis. ILRI, Nairobi, Kenya. Pp. 101-116. 1999.

[11] Codex Alimentarius Commission. Codex Alimentarius Milk and Milk Products Volume 12. 2nd Edition. Food And Agriculture Organization of The United Nations, World Health Organization. 2000.

[12] Scott, R. Cheesemaking Practice. applied Science Publisher, London. 1981.

[13] Geantaresa, E dan Supriyanti, T. Pemanfaatan Ekstrak Kasar Papain Sebagai Koagulan pada Pembuatan Keju Cottage menggunakan Bakteri Streptococcus thermophillus, Lactococcus lactis, dan Leuconostoc mesentroides. Jurnal Sains Kimia dan Teknologi Kimia, Vol. 1, No. 1, hlm: 38-43. 2010.

[14] Murti, T.W. Aneka Keju, Faklutas Peternakan UGM. Yogyakarta. 2004.

[15] Winarno. Kimia Pangan dan Gizi. Jakarta: PT Gramedia Utama. 1982.

[16] Hidayat, N M.C. Mikrobiologi Industri. CV Andi Offset. Jakarta. 2006.

[17] K.Hae-Soo., P Ganesan., Y Hong. Nutritional Benefit in Cheese. In Cheese: Types, Nutrition and Consumption. Nova Science Publisher. Inc. 2011. 